\title{
APLIKASI PREDIKSI JUMLAH PENDERITA PENYAKIT DEMAM BERDARAH DENGUE DI KOTA SEMARANG MENGGUNAKAN JARINGAN SYARAF TIRUAN BACKPROPAGATION
}

\author{
Raditya Lucky Riswanto, Sutikno, dan Indriyati \\ Jurusan Ilmu Komputer / Informatika Fakultas Sains dan Matematika Universitas Diponegoro \\ Email : tik@undip.ac.id, indri52@yahoo.com, raditya.lucky.r@gmail.com
}

\begin{abstract}
Abstrak
IR (incidence rate) DBD Kota Semarang selalu lebih tinggi dari IR DBD Jawa Tengah dan IR DBD Nasional dari tahun 2006 sampai tahun 2012. Tahun 2012 IR DBD Kota Semarang adalah 70.9, tiga kali lebih tinggi dari IR DBD Jawa Tengah yaitu 19,29. Tindakan preventif dari pemerintah diharapkan dapat menekan peningkatan jumlah penderita. Dengan mengetahui peningkatan jumlah penderita, maka pemerintah dapat melakukan tindakan apa yang harus dilakukan untuk menekan penyebaran penyakit. Data jumlah penderita penyakit bersifat kontinu dan memiliki tren yang dinamis, maka metode yang dibutuhkan untuk melakukan prediksi adalah metode yang kompleks dan dapat mempelajari ketidakpastian dalam setiap periode yang dapat diakomodasi dengan algoritma Jaringan Syaraf Tiruan (JST). Salah satu algoritma JST yaitu Backpropagation. Jumlah penderita penyakit DBD per bulan dalam satu tahun digunakan sebagai masukan dengan jumlah penderita penyakit pada satu bulan ke depan sebagai keluaran. Arsitektur backpropagation menggunakan dua belas neuron layer input, satu layer tersembunyi dengan jumlah neuron yang dapat diubah-ubah dan satu neuron pada layer output. Pengujian menghasilkan MAPE terkecil, yaitu 4.48 pada alfa 0.7 dan jumlah neuron tersembunyi sebanyak 50 neuron dengan nilai akurasi 95.52 persen.
\end{abstract}

Kata kunci: penyakit demam berdarah dengue, jaringan syaraf tiruan, backpropagation

\section{PENDAHULUAN}

Profil Kesehatan Kota Semarang tahun 2012 menunjukkan jumlah penderita penyakit DBD cukup tinggi. IR (incidence rate adalah jumlah kasus baru per populasi dalam waktu tertentu) DBD Kota Semarang adalah 70.9 yang bernilai tiga kali lebih tinggi dari IR DBD Jawa Tengah yaitu 19,29 [3].

Tindakan preventif dari pemerintah diharapkan dapat menekan peningkatan jumlah penderita. Dengan mengetahui peningkatan jumlah penderita, maka pemerintah dapat melakukan tindakan apa yang harus dilakukan untuk menekan penyebaran penyakit.

Prediksi adalah kegiatan memperkirakan apa yang terjadi pada masa yang akan datang berdasarkan data yang relevan pada masa lalu dan menempatkannya dalam suatu bentuk model matematis. Data penyakit DBD tersedia dalam bentuk time series dengan rangkaian data $x_{t-1}, x_{t-2}, \ldots, x_{t-p}$ dan data yang akan diprediksi adalah $x_{t}$. Data jumlah penderita penyakit bersifat kontinu dan memiliki tren yang dinamis, maka metode yang dibutuhkan untuk melakukan prediksi adalah metode yang kompleks dan dapat mengakomodasi ketidakpastian dalam setiap periode. Karakteristik tersebut dapat diakomodasi oleh Jaringan Syaraf Tiruan (JST) yang tidak hanya dapat menganalisis data time series, tapi juga dapat mempelajari data untuk dilakukan prediksi pada periode selanjutnya [9].

Salah satu algoritma JST yaitu Backpropagation telah dibuktikan Ria Apriyani dalam Implementation of Artificial Neural Network Backpropagation Method in Predicting Stock Price PT. Indosat Using Matlab7.1 dapat menghasilkan akurasi terbaik sebesar $99.85 \%$ [1]. Algoritma Backpropagation dapat dioptimalkan dengan penambahan algoritma Nguyen Widrow untuk mengoptimalkan inisialisasi bobot. Penelitian Stephen Roy Imantaka dalam Sistem Pengenalan Wajah Berbasis Ensemble Neural Network untuk Citra Inframerah menunjukkan Backpropagation 
dengan metode acak memerlukan iterasi sebanyak 300 epoch, sedangkan dengan metode Nguyen Widrow hanya membutuhkan 60 epoch [5].

\section{TINJAUAN PUSTAKA}

\section{Penyakit Demam Berdarah Dengue}

Demam Berdarah Dengue adalah penyakit demam akut, terutama menyerang anak yang disertai dengan manifestasi pendarahan dan bertendensi menimbulkan shock yang dapat menyebabkan kematian serta sering menimbulkan kejadian luar biasa atau wabah. DBD merupakan penyakit yang disebarkan oleh nyamuk Aedes aegypty yang ditandai dengan demam mendadak, tinggi, dan terus-menerus yang berlangsung selama 2-7 hari disertai dengan tanda pendarahan di kulit, lebam, pendarahan gusi, muntah darah [10].

Di samping itu, penyakit DBD juga dapat ditularkan oleh nyamuk Aedes albopictus, di mana kedua jenis nyamuk ini terdapat di seluruh pelosok Indonesia, kecuali di tempattempat dengan ketinggian lebih dari 1000 meter di atas permukaan laut[10].

Seseorang yang di dalam darahnya mengandung virus dengue merupakan sumber penularan penyakit DBD yang bisa menunjukkan gejala sakit ataupun tidak sakit tergantung kekebalan tubuh terhadap virus tersebut. Jika seseorang digigit oleh nyamuk Aedes aegyptimaka virus dengue masuk bersama darah yang dihisapnya. Di dalam tubuh nyamuk itu, virus akan berkembang biak dengan cara membelah diri dan menyebar di seluruh bagian tubuh nyamuk. Sebagian besar virus itu berada dalam kelenjar liur nyamuk. Dalam tempo satu minggu jumlahnya dapat mencapai puluhan atau ratusan ribu. Selanjutnya pada waktu nyamuk itu menggigit orang lain, maka setelah alat tusuk nyamuk menemukan kapiler darah, sebelum darah dihisap, terlebih dahulu dikeluarkan air liur agar darah yang dihisap tidak membeku. Maka bersama air liur nyamuk inilah virus dengue dipindahkan kepada orang lain[10].

\section{Jaringan Syaraf Tiruan}

Jaringan Syaraf Tiruan (JST) adalah sistem terkomputasi di mana arsitektur operasi diilhami dari pengetahuan tentang sel saraf biologis di dalam otak yang selalu mencoba menstimulasi proses pembelajaran pada otak manusia. Model syaraf ditunjukkan dengan kemampuannya dalam emulasi, analisis, prediksi dan asosiasi. Kemampuan yang dimiliki JST dapat digunakan untuk belajar dan menghasilkan aturan atau operasi dari beberapa contoh atau input yang dimasukkan dan membuat prediksi tentang kemungkinan output yang akan muncul [4].

Setiap pengolahan elemen membuat perhitungan berdasarkan pada jumlah masukan (input). Sebuah kelompok pengolahan elemen disebut layer atau lapisan dalam jaringan. Lapisan pertama adalah input dan yang terakhir adalah output. Lapisan di antara lapisan input dan output disebut dengan lapisan tersembunyi (hidden layer). Jaringan syaraf tiruan merupakan suatu bentuk arsitektur yang terdistribusi paralel dengan sejumlah besar titik dan hubungan antar titik tersebut. Tiap titik berhubungan dari satu titik ke titik lain mempunyai harga yang diasosiasikan sebagai bobot. Setiap titik memiliki nilai yang diasosiasikan sebagai nilai aktivasi titik [4].

\section{Jaringan Syaraf Tiruan Backpropagation}

Backpropagation merupakan salah satu algoritma yang sering digunakan dalam penyelesaian masalah yang rumit. Hal ini dimungkinkan karena jaringan dengan algoritma ini dilatih dengan menggunakan metode belajar terbimbing. Pada jaringan diberikan sepasang pola yang terdiri dari pola masukan dan pola keluaran yang diinginkan. Ketika suatu pola diberikan kepada jaringan, bobot-bobot diubah untuk memperkecil perbedaan pola yang terdiri atas pola keluaran dan pola yang dinginkan. Latihan ini dilakukan berulang-ulang sehingga semua pola yang dikeluarkan jaringan dapat memenuhi pola yang diinginkan [4].

Pelatihan Backpropagation meliputi 3 fase. Fase pertama adalah fase maju. Pola masukan dihitung maju mulai dari layar masukan hingga layar keluaran menggunakan fungsi aktivasi yang ditentukan. Fase kedua adalah fase mundur. Selisih antara keluaran jaringan dengan target yang diinginkan merupakan kesalahan yang terjadi. Kesalahan tersebut dipropagasikan mundur, dimulai dari 
garis yang berhubungan langsung dengan unitunit di layar keluaran. Fase ketiga adalah modifikasi bobot untuk meurunkan kesalahan yang terjadi [8].

Algoritma pelatihan untuk jaringan dengan satu layer tersembunyi menggunakan fungsi aktivasi sigmoid biner adalah sebagai berikut [8]:

1. Inisialisasi bobot

2. Jika kondisi penghentian belum terpenuhi lakukan langkah 3-9

3. Untuk setiap pasang data pelatihan, lakukan langkah 4-9

Fase I: Propagasi Maju

4. Tiap unit masukan $\left(x_{i}, \mathrm{i}=1,2,3, \ldots, n\right)$ menerima sinyal $x_{i}$ dan meneruskan sinyal tersebut pada semua lapisan tersembunyi.

5. Hitung semua keluaran di unit tersembunyi $z_{j}$ $(j=1,2,3, \ldots, p) \cdot v_{j 0}$ adalah nilai bobot bias (b) dari layer input ke layer tersembunyi.

$$
\begin{aligned}
& z_{-} \text {net }_{j}=v_{j 0}+\sum_{i=1}^{n} x_{i} v_{j i} \\
& z_{j}=f\left(z_{-} n e t_{j}\right)=\frac{1}{1+e^{-z_{-} n e t_{j}}}
\end{aligned}
$$

6. Hitung semua keluaran jaringan di unit output $y_{k}(k=1,2,3, \ldots, m)$ dengan. $w_{k 0}$ adalah nilai bobot bias (b) dari layer tersembunyi ke layer output.

$$
\begin{aligned}
& y_{-} \text {net }_{k}=w_{k 0}+\sum_{j=1}^{p} z_{j} w_{k j} \\
& y_{k}=f\left(y_{\text {net }_{k}}\right)=\frac{1}{1+e^{-y_{-} n e t_{k}}} .
\end{aligned}
$$

\section{Fase II: Propagasi Mundur}

7. Hitung faktor $\delta$ unit keluaran berdasarkan kesalahan di setiap unit keluaran $y_{k}(k=1,2$, ..., $m)$

$$
\begin{aligned}
\delta_{k} & =\left(t_{k}-y_{k}\right) f^{\prime}\left(y_{\text {net }_{k}}\right) \\
& =\left(t_{k}-y_{k}\right) y k\left(1-y_{k}\right)
\end{aligned}
$$

Hitung suku perubahan bobot $\Delta w_{k j}$ dengan laju pembelajaran $(\alpha) .(k=1,2, \ldots, m)$ dan $(j=0,1, \ldots, p) . z_{0}$ adalah nilai bias layer tersembunyi yang bernilai satu.

$\Delta w_{k j}=\alpha \delta_{k} z_{j}$
8. Hitung faktor $\delta$ unit tersembunyi berdasarkan kesalahan di setiap unit tersembunyi $z_{j}(\mathrm{j}=1$, $2, \ldots, p)$ dan faktor $\delta$ unit tersembunyi.

$$
\begin{aligned}
& \delta_{-} \text {net }_{j}=\sum_{k=1}^{m} \delta_{k} w_{k j} \\
& \delta_{j}=\delta_{\text {net }_{j}} f^{\prime}\left(z_{\text {net }_{j}}\right) \\
& =\delta_{-} \text {net }_{j} z_{j}\left(1-z_{j}\right)
\end{aligned}
$$

Hitung suku perubahan bobot $\Delta \mathrm{v}_{j i} . x_{0}$ adalah nilai bias layer input yang bernilai satu.

$\Delta \mathrm{v}_{j i}=\alpha \delta_{j} x_{j}$

\section{Fase III Perubahan Bobot}

9. Hitung semua perubahan bobot. $(k=1,2, \ldots$,

$$
\begin{aligned}
& m) \text { dan }(j=0,1, \ldots, \mathrm{p}) . \\
& w_{k j}(\text { baru })=w_{k j}(\text { lama })+\Delta w_{k j} \ldots \\
& \mathrm{v}_{j i}(\text { baru })=\mathrm{v}_{j i}(\text { lama })+\Delta \mathrm{v}_{j i} \ldots \ldots \ldots
\end{aligned}
$$

Setelah pelatihan selesai dilakukan, jaringan dapat dipakai untuk pengenalan pola. Dalam hal ini, hanya propagasi maju (langkah 5 dan 6) saja yang dipakai untuk menentukan keluaran jaringan.

\section{MSE (Means Square Error)}

Perhitungan MSE digunakan untuk mengukur apakah jaringan saraf tiruan dapat melakukan proses belajar dengan baik. MSE ini merupakan pengukuran ketepatan jaringan saraf tiruan terhadap data target pembelajaran. MSE pada keluaran jaringan saraf tiruan merupakan selisih antara keluaran yang didapat dari proses pembelajaran dengan target yang diinginkan dari masukan data tertentu. Data pembelajaran merupakan data yang dijadikan sebagai pembanding pada proses pembelajaran, sedangkan pada proses pengujian, data yang dipakai adalah data uji.

Cara menghitung MSE untuk kumpulan data d pada jaringan saraf tiruan dengan kumpulan neuron keluaran [2].

$$
M S E=\frac{\sum_{d} \sum_{k \in \text { outputs }}\left(t_{k}-O_{k}\right)^{2}}{n_{d} n_{\text {outputs }}}
$$

\section{Keterangan :}

$t_{\mathrm{k}}$ adalah nilai target neuron keluaran ke-k $\mathrm{o}_{\mathrm{k}}$ adalah nilai output neuron keluaran ke-k $\mathrm{n}_{\mathrm{d}}$ adalah jumlah data pembelajaran $\mathrm{n}_{\text {output }}$ adalah jumlah neuron keluaran 


\section{MAPE (Means Absolute Percentage Error)}

Prediksi tidak selalu tepat karena teknik yang digunakan belum tentu sesuai dengan sifat datanya. Oleh karena itu perlu diadakan presentase kebenaran prediksi sehingga dapat diketahui sesuai atau tidaknya teknik prediksi yang digunakan. Pada prinsipnya, perhitungan presentase kebenaran prediksi dilakukan dengan membandingkan hasil prediksi dengan kenyataan yang terjadi.

Perhitungan besarnya error peramalan dihitung dengan menggunakan MAPE yang merupakan nilai tengah presentase kesalahan absolut dari suatu prediksi dengan persamaan (3) [7].

$$
M A P E=\frac{\sum_{t=1}^{n} \frac{\left|x_{t}-F_{t}\right|}{x_{t}}}{n}
$$

Keterangan :

$x_{t}$ adalah nilai data sebenarnya periode ke-t $F_{t} \mathrm{O}_{\mathrm{k}}$ adalah nilai data hasil prediksi periode ke-t

$n$ adalah banyaknya data

Jika MAPE $<25 \%$ maka hasil prediksi dapat diterima secara memuaskan, sebaliknya jika MAPE $>25 \%$ maka hasil prediksi kurang memuaskan [7].

\section{Algoritma Inisialisasi Nguyen Widrow}

Bobot awal akan mempengaruhi apakah jaringan mencapai titik minimum lokal atau global dan seberapa cepat konvergensinya. Nguyen dan Widrow (1990) mengusulkan cara membuat inisialisasi bobot dan bias ke unit tersembunyi sehingga menghasilkan iterasi lebih cepat, misalkan :

$\mathrm{n}=$ jumlah unit masukan

$\mathrm{p}=$ jumlah unit tersembunyi

$\beta=$ faktor skala, dihitung dengan persamaan (4)

$$
\beta=0.7 \sqrt[n]{p}
$$

Algoritma inisialisasi Nguyen Widrow adalah sebagai berikut [8] :

1. Inisialisasi semua bobot ( $\mathrm{v}_{\mathrm{ji}}$ (lama)) dengan bilangan acak dalam interval $[-0.5,0.5]$

2. Hitung $v_{j}$ dengan persamaan (5)

$$
|| v_{j}||=\sqrt{v_{j 1}^{2}+v_{j 2}^{2}+\cdots+v_{j n}^{2}}
$$

3. Bobot yang dipakai sebagai inisialisasi menggunakan persamaan (6)

$$
v_{j i}=\frac{\beta v_{j i}(\text { lama })}{\left\|v_{j}\right\|}
$$

4. Bias yang dipakai sebagai inisialisasi $\mathrm{V}_{\mathrm{j} 0}$ adalah bilangan acak antara $-\beta$ dan $\beta$

\section{Prediksi Time Series}

Prediksi (forecasting) merupakan kegiatan memprediksi nilai-nilai sebuah variabel berdasarkan nilai yang diketahui dari variabel tersebut atau variabel yang berhubungan. Menurut sifatnya, teknik prediksi terbagi menjadi dua jenis yaitu teknik kualitatif dan teknik kuantitatif. Teknik kuantitatif dikelompokkan dalam dua jenis [11]:

\section{Model Time Series (Runtun Waktu)}

Pada model Time Series, peramalan masa mendatang dilakukan berdasarkan nilai data masa lalu atau disebut data historis. Tujuan metode ini adalah menemukan pola dalam deret data historis dan memanfaatkan pola deret tersebut untuk peramalan masa mendatang. Keuntungan dalam menggunakan model ini adalah peramalan dapat dilakukan secara lebih sederhana dibandingkan dengan model kausal.

\section{Model kausal}

Model Kausal merupakan suatu model yang mengasumsikan faktor yang diramalkan menunjukkan suatu hubungan sebab akibat dalam satu atau lebih variabel bebas dan menggunakannya untuk meramalkan nilai mendatang dari suatu variabel tak bebas. Keuntungan dalam menggunakan model ini adalah dapat menghasilkan tingkat keberhasilan yang lebih besar dalam pengambilan keputusan yang bijaksana.

Data Time series adalah data yang menggambarkan suatu objek dari waktu ke waktu atau periode secara historis dan terjadi berurutan.Kecerdasan Buatan telah digunakan secara luas untuk fungsi pengenalan dan peramalan. Salah satu diantaranya adalah jaringan syaraf tiruan (JST). Keuntungan yang paling signifikan dari model JST dengan model nonlinear yang lain adalah bahwa JST mampu memberikan pendekatan secara umum untuk mengenali pola masukan dengan derajat keakuratan yang cukup besar. Kekuatannya berasal dari proses informasi data yang paralel [6]. 


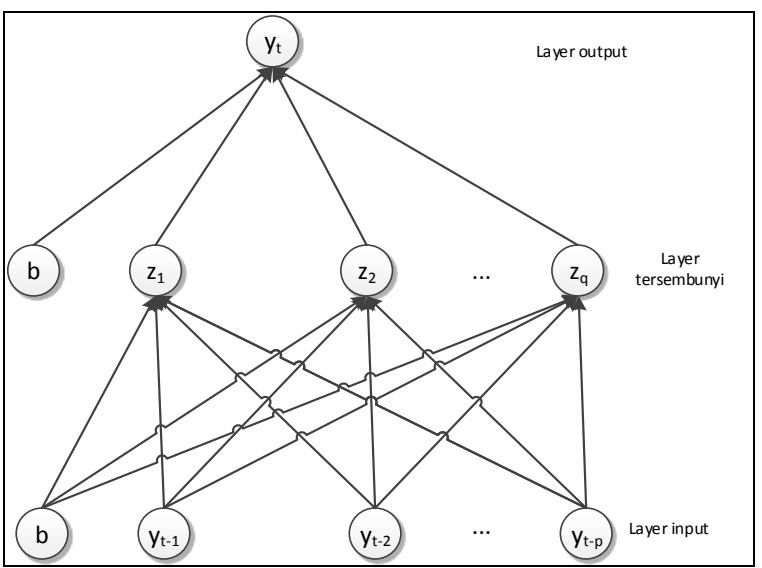

Gambar 1 Arsitektur Jaringan Syaraf Tiruan untuk time series

Tidak ada asumsi yang tegas untuk bentuk model yang diperlukan dalam pembentukan model karena model jaringan sangat ditentukan oleh karakteristik dari data. Jaringan Backpropagation dengan satu lapisan tersembunyi adalah model yang paling banyak digunakan untuk prediksi time series. Karakteristik model tersebut terdiri dari tiga lapisan pengolah yang masing-masing neuron pemroses yang dihubungkan dengan bobot yang dapat dilihat pada gambar 1. Hubungan antara keluaran $\left(y_{t}\right)$ dan masukan $\left(y_{t-1}, \ldots, y_{t-p}\right) \ldots$ mempunyai model matematis seperti persamaan (7) $[6]$.

$$
\begin{aligned}
& y_{t}=w_{0}+ \\
& \sum_{j=1}^{q} w_{j} g\left(w_{0 j} \sum_{i=1}^{p} w_{i j} y_{t-i}\right) .
\end{aligned}
$$

Di mana $w_{i j}(i=0,1,2, \ldots, p ; j=$ $1,2, \ldots, q)$ dan $w_{j}(j=0,1,2, \ldots, q)$ adalah parameter yang sering disebut bobot, $p$ adalah jumlah neuron lapisan input, dan $q$ adalah jumlah neuron lapisan tersembunyi.

\section{PEMBAhaSAN Gambaran Umum}

Aplikasi pada penelitian ini merupakan perangkat lunak yang berfungsi untuk melakukan prediksi mengenai jumlah penderita penyakit DBD yang terjadi di Kota Semarang. Aplikasi yang dikembangkan berbasis web dengan menggunakan data minimal dua tahun yang diambil dari Dinas Kesehatan Kota
Semarang. Gambaran Umum aplikasi dapat dilihat pada gambar 2 .

Aplikasi ini hanya memiliki dua jenis pengguna, yaitu Admin dan pengguna umum. Admin adalah pengguna yang dapat mengelola data penyakit, melakukan pelatihan, pengujian, dan prediksi. Data penyakit terdiri dari bulan, tahun dan jumlah penderita penyakit DBD. Pelatihan dilakukan oleh admin dengan memasukkan variabel jaringan berupa alfa, jumlah neuron tersembunyi, maksimal epoch, minimum error. Proses pelatihan menghasilkan bobot akhir yang selanjutnya digunakan untuk pengujian dan prediksi. Pengujian menghasilkan error yang akan dibandingkan dengan hasil pengujian lainnya, sehingga akan didapatkan variabel jaringan yang menghasilkan error terkecil untuk digunakan prediksi. Ketika proses prediksi dilakukan akan dihasilkan nilai prediksi jumlah penderita penyakit DBD satu bulan ke depan yang kemudian sistem akan menganalisis apakah hasil tersebut mengalami peningkatan atau penurunan dari bulan sebelumnya. Pengguna umum dapat melihat data penyakit dan melihat status prediksi.

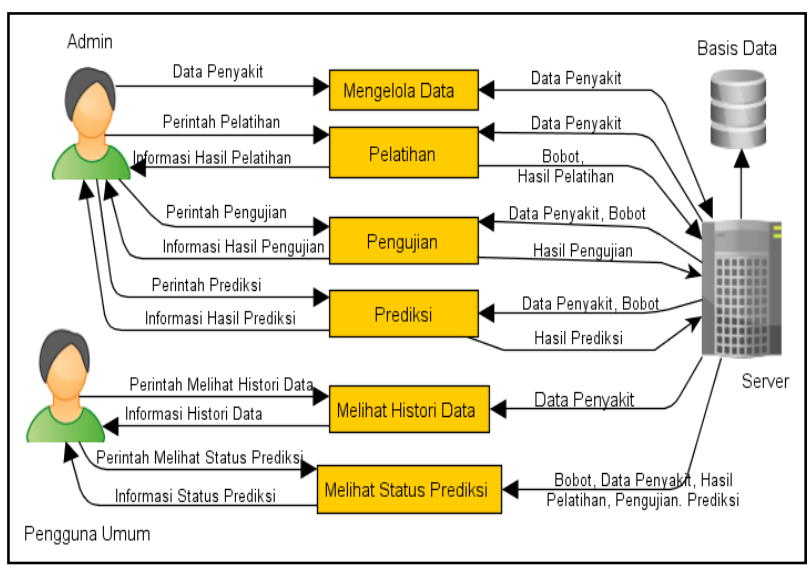

Gambar 2 Gambaran Umum Aplikasi

\section{Use Case}

Use case merupakan deskripsi urutan tindakan yang dilakukan aplikasi yang berpengaruh kepada actor dari aplikasi. Terdapat enam use case dalam aplikasi, yaitu usecase mengelola data, melakukan pelatihan, melakukan pengujian, melakukan prediksi, melihat histori data, dan melihat status prediksi. Penjelasan masing-masing use case ada pada Tabel 1. 
Tabel 1 Daftar Use Case Aplikasi

\begin{tabular}{|c|c|c|}
\hline No & Use Case & Deskripsi \\
\hline 1 & $\begin{array}{l}\text { Mengelola } \\
\text { data }\end{array}$ & $\begin{array}{l}\text { Admin dapat mengelola data jumlah } \\
\text { penderita penyakit DBD setiap bulan } \\
\text { yang diperlukan untuk melakukan } \\
\text { pelatihan, pengujian dan prediksi }\end{array}$ \\
\hline 2 & $\begin{array}{l}\text { Melakukan } \\
\text { Pelatihan }\end{array}$ & $\begin{array}{l}\text { Admin memerintahkan aplikasi } \\
\text { untuk melakukan pelatihan } \\
\text { menggunakan metode } \\
\text { backpropagation berdasarkan } \\
\text { variabel jaringan yang dimasukkan, } \\
\text { yaitu alfa, jumlah neuron } \\
\text { tersembunyi, maksimum epoch, } \\
\text { minimum error }\end{array}$ \\
\hline 3 & $\begin{array}{l}\text { Melakukan } \\
\text { Pengujian }\end{array}$ & $\begin{array}{l}\text { Admin memerintahkan aplikasi } \\
\text { untuk melakukan pengujian } \\
\text { menggunakan metode } \\
\text { backpropagation }\end{array}$ \\
\hline 4 & $\begin{array}{l}\text { Melakukan } \\
\text { Prediksi }\end{array}$ & $\begin{array}{l}\text { Admin memerintahkan aplikasi } \\
\text { untuk menghitung prediksi } \\
\text { menggunakan metode } \\
\text { backpropagation }\end{array}$ \\
\hline 5 & $\begin{array}{l}\text { Melihat } \\
\text { Histori Data }\end{array}$ & $\begin{array}{l}\text { Semua pengguna dapat melihat data } \\
\text { di dalam aplikasi yang digunakan } \\
\text { untuk melakukan prediksi }\end{array}$ \\
\hline 6 & $\begin{array}{l}\text { Melihat } \\
\text { Status } \\
\text { Prediksi }\end{array}$ & $\begin{array}{l}\text { Semua pengguna aplikasi dapat } \\
\text { melihat status prediksi }\end{array}$ \\
\hline
\end{tabular}

\section{Arsitektur Jaringan}

Arsitektur jaringan yang digunakan dapat dilihat pada gambar 3 yang terdapat tiga layer yaitu 12 neuron pada layer masukan, 3 neuron pada layer tersembunyi dan satu neuron pada layer keluaran. Jumlah neuron pada layer tersembunyi merupakan variabel yang dapat diubah. Data yang diinput berupa data time series per bulan dengan pola inputan data yaitu $x_{t-1}, x_{t-2}, \ldots, x_{t-12}$. Output yang dihasilkan berupa nilai $x_{t}$ yang merupakan nilai $x$ pada satu bulan berikutnya.

\section{Pelatihan dan Pengujian}

Data jumlah penderita penyakit Demam Berdarah Dengue(DBD) tersedia dalam kurun waktu delapan tahun yaitu mulai tahun 2006 sampai 2013 dengan jumlah 96 data. Data dibagi menjadi dua bagian yaitu data pelatihan sebanyak 71 (70\% persen dari 96) dan data pengujian sebanyak 25 (30\% persen dari 96 ).

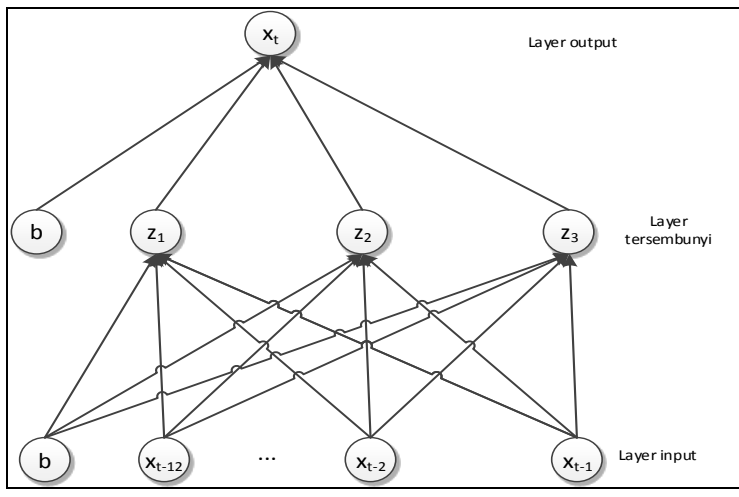

Gambar 3 Arsitektur Jaringan

Hasil Pelatihan dan pengujian dari jaringan syaraf tiruan dilakukan dengan variasi jumlah neuron pada layer tersembunyai pada beberapa nilai alfa, serta batas epoch maksimal dibatasi sampai 100.000 epoch. Pada setiap pengujian pelatihan dilihat durasi pelatihan dan nilai MSEnya. Sedangkan pada pengujian dilihat Nilai MAPE dan tingkat akurasinya. Hasil dari pelatihan dan pengujian jaringan syaraf tiruan backpropagation tersebut yaitu seperti pada tabel 3.

Setelah dilakukan pelatihan terdapat dua pelatihan yang tercepat dengan durasi waktu 19 menit, yaitu pada alfa 0.3 , jumlah neuron tersembunyi sebanyak 10 neuron dan pada alfa 0.5 , jumlah neuron tersembunyi sebanyak 10 neuron. Kedua hasil pelatihan ditunjukkan pada baris yang berwarna abu-abu muda.

Pengujian menghasilkan MAPE terkecil, yaitu 4.48 pada alfa 0.7 dan jumlah neuron tersembunyi sebanyak 50 neuronyang ditunjukkan pada baris yang berwarna abu-abu tua dengan nilai akurasi 95.52 persen.

Variabel jaringan dengan hasil MSE terkecil kemudian dianalisis perbandingan antara nilai prediksi dan nilai observasi dalam bentuk grafik dan tabel data yang dapat dilihat pada gambar 4. Gambar 4 menunjukkan hasil prediksi dan nilai observasi memiliki error pada empat dari lima data dan satu data tepat sama dengan nilai observasi sehingga menghasilkan akurasi sebesar 95.52 persen. 
Tabel 3 Hasil pelatihan dan pengujian penyakit Demam Berdarah Dengue

\begin{tabular}{|c|c|c|c|c|c|c|}
\hline \multirow{2}{*}{$\begin{array}{l}\text { Jumlah } \\
\text { Neuron }\end{array}$} & \multirow{2}{*}{ Alfa } & \multicolumn{3}{|c|}{ Pelatihan } & \multicolumn{2}{|c|}{ Pengujian } \\
\hline & & Epoch & Durasi & MSE & MAPE & Akurasi \\
\hline 10 & 0.3 & 100000 & 19 Menit & $5.14 \times 10^{-5}$ & 13.09 & 86.91 \\
\hline 30 & 0.3 & 100000 & 59 Menit & $5.88 \times 10^{-5}$ & 11.91 & 88.09 \\
\hline 50 & 0.3 & 100000 & 2 Jam. 25 Menit & $2.74 \times 10^{-5}$ & 8.74 & 91.26 \\
\hline 70 & 0.3 & 100000 & 2 Jam. 25 Menit & 0.55 & 1137 & 0 \\
\hline 90 & 0.3 & 100000 & 3 Jam. 22 Menit & 0.55 & 1137 & 0 \\
\hline 10 & 0.4 & 100000 & 23 Menit & $1.06 \times 10^{-5}$ & 5.63 & 94.37 \\
\hline 30 & 0.4 & 100000 & 1 Jam. 13 Menit & $1.13 \times 10^{-5}$ & 5.38 & 94.62 \\
\hline 50 & 0.4 & 100000 & 1 Jam. 43 Menit & $1.56 \times 10^{-5}$ & 7.28 & 92.72 \\
\hline 70 & 0.4 & 100000 & 2 Jam. 30 Menit & 0.55 & 1137 & 0 \\
\hline 90 & 0.4 & 100000 & 3 Jam. 13 Menit & 0.55 & 1137 & 0 \\
\hline 10 & 0.5 & 100000 & 19 Menit & $6.14 \times 10^{-5}$ & 15.31 & 84.69 \\
\hline 30 & 0.5 & 100000 & 59 Menit & $1.52 \times 10^{-5}$ & 6.03 & 93.97 \\
\hline 50 & 0.5 & 100000 & 1 Jam. 39 Menit & $1.77 \times 10^{-5}$ & 7.31 & 92.69 \\
\hline 70 & 0.5 & 100000 & 2 Jam. 22 Menit & 0.55 & 1137 & 0 \\
\hline 90 & 0.5 & 100000 & 3 Jam. 19 Menit & 0.55 & 1137 & 0 \\
\hline 10 & 0.6 & 100000 & 21 Menit & $3.97 \times 10^{-5}$ & 9.29 & 90.71 \\
\hline 30 & 0.6 & 100000 & 1 Jam. 3 Menit & $4.29 \times 10^{-5}$ & 11.91 & 88.09 \\
\hline 50 & 0.6 & 100000 & 1 Jam. 56 Menit & $1 \times 10^{-5}$ & 5.36 & 94.64 \\
\hline 70 & 0.6 & 100000 & 3 Jam. 10 Menit & 0.55 & 1137 & 0 \\
\hline 90 & 0.6 & 100000 & 3 Jam. 21 Menit & 0.55 & 1137 & 0 \\
\hline 10 & 0.7 & 100000 & 25 Menit & $1.26 \times 10^{-5}$ & 6.14 & 93.86 \\
\hline 30 & 0.7 & 100000 & 1 Jam. 15 Menit & $1 \times 10^{-5}$ & 5.17 & 94.83 \\
\hline 50 & 0.7 & 100000 & 1 Jam. 28 Menit & $1 \times 10^{-5}$ & 4.48 & 95.52 \\
\hline 70 & 0.7 & 100000 & 2 Jam. 41 Menit & $6.09 \times 10^{-5}$ & 14.01 & 85.99 \\
\hline 90 & 0.7 & 100000 & 3 Jam. 10 Menit & 0.55 & 1137 & 0 \\
\hline
\end{tabular}




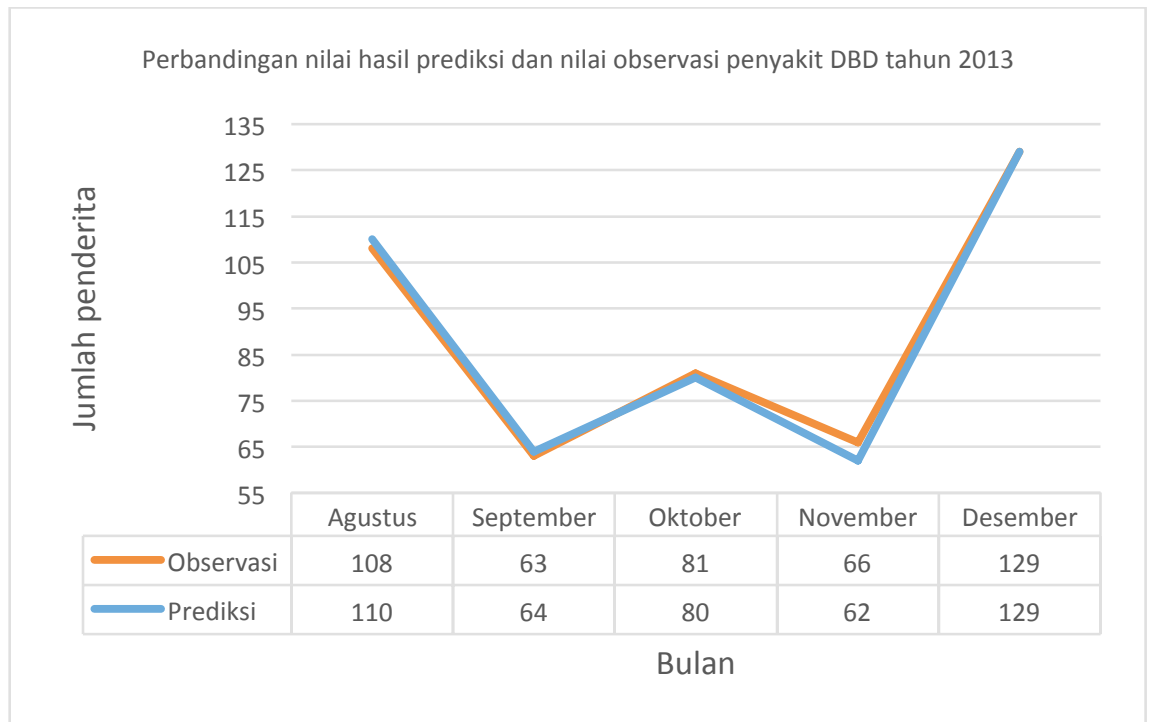

Gambar 4 Perbandingan nilai hasil prediksi dan nilai observasi penyakit DBD pada tahun 2013

\section{KESIMPULAN}

Pelatihan Jaringan Syaraf Tiruan Backpropagationmenunjukkan dua pelatihan paling cepat dengan durasi waktu 19 menit, yaitu pada alfa 0.3, jumlah neuron tersembunyi sebanyak 10 neuron dan pada alfa 0.5 , jumlah neuron tersembunyi sebanyak 10 neuron.

Pengujian menghasilkan MAPE terkecil, yaitu 4.48 pada alfa 0.7 dan jumlah neuron tersembunyi sebanyak 50 neuron dengan nilai akurasi 95.52 persen.

\section{DAFTAR PUSTAKA}

[1] Apriyani R., 2010, "Implementation Of Artificial Neural Network Backpropagation Method In Predicting Stock Price PT. Indosat Using Matlab 7.1", Program Pasca Sarjana, Universitas Gunadarma, Depok.

[2] Darmawan D., 2010, "Pengenalan Wajah dengan Metode Backpropagation Menggunakan Kamera CCTV Inframerah", Program Sarjana Ekstensi, Universitas Indonesia, Depok.

[3] Dinas Kesehatan Kota Semarang, 2012, "Profil Kesehatan Kota Semarang 2012", http://www.dinkesjatengprov.go.id/, diakses pada tanggal 1 November 2013 pukul 08.15 WIB.
[4] Hermawan A., 2006, "Jaringan Syaraf Tiruan Teori dan Aplikasi", Andi Offset, Yogyakarta.

[5] Imantaka S. R., 2010, "Sistem Pengenal Wajah Berbasis Ensemble Neural Network untuk Citra Inframerah", Program Sarjana, Universitas Indonesia, Depok.

[6] Khashei M. dan Mehdi Bijari, 2011, "Which Methodology is Better for Combining Linear and Nonlinear Models for Time Series Forecasting", Journal of Industrial and Systems Engineering, 4(4):265-285.

[7] Mustaziri, 2012, "Sistem Pakar Fuzzy Untuk Optimasi Penggunaan Bandwidth Jaringan Komputer", Program Pasca Sarjana, Universitas Diponegoro, Semarang.

[8] Siang, Jong Jek, 2005, "Jaringan Syaraf Tiruan dan Pemprogramannya menggunakan Matlab", Andi Offset, Yogyakarta.

[9] Singh S., et al, 2011, "Time Series based Temperature Prediction using Back Propagation with Genetic Algorithm Technique", IJCSI International Journal of Computer Science Issues, 8(3):28-32.

[10]Suhardiono, 2005, "Sebuah Analisis Faktor Risiko Perilaku Masyarakat terhadap Kejadian Demam Berdarah Dengue (DBD) di Kelurahan Helvetia Tengah, Meda, 
Tahun 2005”, Jurnal Mutiara Kesehatan Indonesia, 1(2): 48-65.

[11] Tanjung I. H., 2012, "Peramalan Jumlah Penjualan Distributor Telur Terhadap
Permintaan Pasar Menggunakan Metode Average-Based Fuzzy Time Series (ABFTS)", Program Sarjana, Universitas Sumatera Utara, Medan. 